\title{
Response of sugar beet to irrigation interval, harvesting time and integrated use of farmyard manure and nitrogen fertilizer
}

\author{
Fatemeh Heidarian', Asad Rokhzadi ${ }^{1 *}$, Fardin Mirahmadi ${ }^{2}$ \\ ${ }^{1}$ Department of Agronomy, Sanandaj Branch, Islamic Azad University, Sanandaj, Iran \\ ${ }^{2}$ Department of Food Science \& Technology, Sanandaj Branch, Islamic Azad University, Sanandaj, Iran \\ *Corresponding author, E-mail: asadrokh@yahoo.com
}

\begin{abstract}
Considering the importance of interactive effects of irrigation, fertilizer and harvest date this experiment was aimed to study the growth and yield response of spring-sown sugar beet to the harvest date and the application of nitrogen and farmyard manure under two irrigation regimes: well watered and moderate drought stress. Results indicated that irrigation significantly affected taproot growth; moderate drought stress led to an increase in root diameter. Leaf dry weight was increased by the application of nitrogen fertilizer in the well watered condition but decreased under water deficit condition. The combined application of 50\% nitrogen fertilizer and 50\% farmyard manure resulted in increased root yield by 28 and 32\% compared with single application of nitrogen and farmyard manure fertilizers, respectively. Interaction effect of factors showed that under the moderate drought stress and availability of the recommended dose of nitrogen in soil, a late harvest date can be recommended to prevent loss of sugar content in sugar beet roots.
\end{abstract}

Key words: harvest, drought stress, sugar beet, water regime.

Abbreviations: FYM, farmyard manure; WD, water defficit; WW, well watered.

\section{Introduction}

Optimum irrigation management is one of the most important factors in sugar beet production, as it can increase yield and reduce water costs, fertilizer leaching and soil erosion (Reddy et al. 2007). Sugar beet can grow in a wide range of water conditions and irrigation treatments (Davidoff, Hanks 1989). This crop is compatible with soil water deficit. With increasing irrigation interval, the root to shoot ratio is increased and water uptake from the lower layers of soil through the deep roots can be remarkably increased (Camposeo, Rubino 2003). Several studies have been conducted on the effects of irrigation regime changes on various traits of sugar beet (Hang, Miller 1986; Groves, Bailey 1997; Choluj et al. 2004; Monti et al. 2006; Mahmoodi et al. 2008; Morillo-Vellarde 2010; Kiymaz, Ertek 2015; Malik et al. 2018; Zare Abyaneh et al. 2017). Irrigation management in sugar beet cultivation, interacting with factors such as nitrogen fertilizer and harvesting date, can affect the quantity and quality of sugar beet root.

The optimum fertilizers application, especially nitrogen fertilizer, plays an essential role in enhancement of the beet sugar quantity and quality. Nitrogen is one of the most important nutrients for sugar beet. Hence its amount and application mode during plant growth is of great importance. Soil nitrogen deficiency can reduce vegetative growth and root yield while increasing sugar content. On the other hand, a rise in soil nitrogen increases root and sugar yield, as well as root impurities while decreasing the sugar content (Oliveira et al. 1993; Tsialtas, Maslaris 2005; Moore et al. 2009). High nitrogen mobility and its role in the environmental contamination especially groundwater resources pollution, as well as its negative impact on the sugar beet quality are considered as limiting factors for nitrogen application (Yousefabadi, Abdollahian-Noghabi 2011). In addition, since the soil of most Iranian farmlands are poor in organic matter, the application of organic fertilizers and manures can contribute to increase soil organic matter and fertility while reducing the dependence on nitrogen fertilizer. Sugar beet growers can use manure or compost to meet nitrogen requirements of sugar beet. A study conducted by Lehrsch et al. (2015) showed that the sugar and root yield resulting from the application of conventional manure or compost was equivalent to that resulting from urea application.

Many experiments have been performed on the benefits of manure and organic fertilizer application, instead of chemical fertilizers, in the production of various crops. The results of experiments on application of manure and compost on wheat growth and yield showed that these additions significantly improved wheat growth and yield parameters, and it was concluded that a combination of chemical fertilizer and manures could be more effective 
than pure chemical fertilizer (Ibrahim et al. 2008). Different chemical fertilizer and manure application treatments in sorghum cultivation indicated that simultaneous application of manure and $50 \%$ of the recommended inorganic fertilizer rate caused equal or greater yield than the application of $100 \%$ recommended inorganic fertilizer (Bayu et al. 2006). A study on the effects of different combinations of organic and inorganic fertilizers on faba bean yield in acidic soil recommended the application of $50 \%$ manure with a ratio of $4 \mathrm{t} \mathrm{ha}^{-1}$ combined with $15 \mathrm{~kg}$ of phosphorus and $3.2 \mathrm{tha}^{-1}$ of lime as the best treatment to increase faba bean yield (Fekadu et al. 2018). The effects of different levels of manure application including 0,5 and 10 tons/ha in rice cultivation showed a significant increase in grain yield from $1.35 \mathrm{t} \mathrm{ha}^{-1}$ (in control treatment) to 3.05 and $3.31 \mathrm{tha}^{-1}$ in treatments of 5 and $10 \mathrm{tha}^{-1}$, respectively, indicating that the use of farmyard manure as an organic soil amendment can be useful in increasing yield especially in areas with low fertility soils and low moisture content (Saidia, Mrema 2017).

Time of harvesting is another factor that can affect the yield and quality of sugar beet root. The results of experiments on the effects of time of harvesting on sugar beet are variable and largely depend on the climatic conditions of each region. In an experiment carried out by Davidoff and Hanks (1989), it was showed that the response of sugar beet yield to changing in time of harvesting depended on irrigation regimes whereas sugar content was not affected by harvesting date. In another study on autumn-sown sugar beet, Taleghani et al. (2011) examined the effects of four harvest dates with one-month intervals from late May to late August and found that the shift of harvest from May to June caused a significant increase in sugar and root yields, and in the sugar content of root.

Although much research has been conducted on the effects of different organic and inorganic fertilizers on sugar beet traits, there is limited information regarding the interactive effects of irrigation, fertilizer and harvest date on sugar beet growth and yield. Thus, this study was conducted to determine sugar beet response to changes in harvest dates and application of manure and nitrogen fertilizer under two different irrigation conditions in spring cultivation conditions.

\section{Materials and methods}

\section{Characteristics of the experimental site}

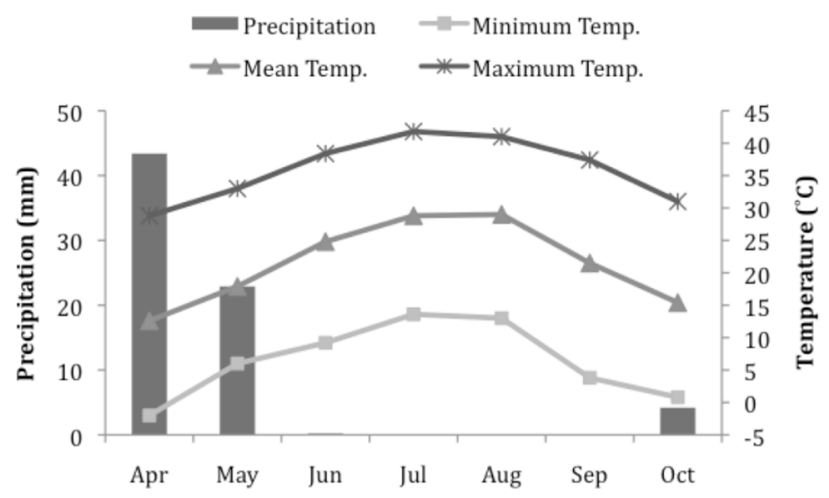

Fig. 1. Precipitation and temperature in the growing season of 2016 at the experimental site.

The study was carried out at the experimental farm of Islamic Azad University, Sanandaj Branch (35 $10^{\circ} \mathrm{N}$ and $46^{\circ} 59^{\prime} \mathrm{E}$; elevation $1393 \mathrm{~m}$ above sea level) during spring and summer 2016. The long-term annual rainfall and average temperature of the area are $471 \mathrm{~mm}$ and $13.4^{\circ} \mathrm{C}$, respectively. The monthly precipitation and temperature of the experimental site in the growing season are shown in Fig. 1, and the experimental farm soil characteristics in Table 1.

\section{Experimental design, treatments and management}

The experiment was performed as split-split plots in a randomized complete block design with three replications. The main factor was irrigation regime with two levels of well watered (WD, irrigation interval of 5 days) and moderate drought stress [water deficit (WD), irrigation interval of 10 days]. The sub-factor was fertilizer application with three levels: (i) $\mathrm{N}$, recommended dose of nitrogen fertilizer (200 kg ha ${ }^{-1}$ ); (ii) FYM, recommended dose of farmyard manure $\left(30 \mathrm{t} \mathrm{ha}^{-1}\right)$ and (iii) N+FYM, a combination of $50 \%$ nitrogen $\left(100 \mathrm{~kg} \mathrm{ha}^{-1}\right)$ and 50\% farmyard manure (15 $\mathrm{t} \mathrm{ha}^{-}$ $\left.{ }^{1}\right)$. In addition, two harvest dates (October 1 and 31 ) were considered as sub-sub factor levels.

The Iranian sugar beet cultivar SBSI003 with monogerm seeds used in the study was obtained from Kermanshah Agricultural Research Center. Nitrogen fertilizer and manure were from the urea source and cow manure respectively. The properties of the cow manure are as given in Table 2. Each experimental plot consisted of five ridges, $7 \mathrm{~m}$ in length with $50 \mathrm{~cm}$ space between the ridges and $20 \mathrm{~cm}$ between the plants on each ridge. Sowing was carried out manually on May 18, 2016. Manual weed

Table 1. Physical and chemical properties of the soil of the experimental site. OC, organic carbon: TNV, total neutralizing value; EC, electrical conductivity

\begin{tabular}{|c|c|c|c|c|c|c|c|c|c|c|c|}
\hline Soil depth $(\mathrm{cm})$ & Clay (\%) & $\begin{array}{l}\text { Silt } \\
(\%)\end{array}$ & $\begin{array}{c}\text { Sand } \\
(\%)\end{array}$ & Texture & OC (\%) & TNV (\%) & $\mathrm{pH}$ & $\begin{array}{c}\mathrm{EC} \\
\left(\mathrm{dS} \mathrm{m}^{-1}\right)\end{array}$ & N (\%) & $\begin{array}{c}\mathrm{P} \\
\left(\mathrm{mg} \mathrm{kg}^{-1}\right)\end{array}$ & $\begin{array}{c}\mathrm{K} \\
\left(\mathrm{mg} \mathrm{kg}^{-1}\right)\end{array}$ \\
\hline $0-30$ & 32.28 & 34 & 33.72 & Loam & 1.13 & 4.50 & 7.69 & 0.489 & 0.11 & 14.03 & 234.4 \\
\hline $30-60$ & 32.28 & 28 & 39.72 & Clay loam & 0.83 & 7.25 & 8.01 & 0.535 & 0.08 & 10.86 & 205.0 \\
\hline
\end{tabular}


Table 2. Composition of the cow manure used in the experiment. EC, electrical conductivity; OC, organic carbon; OM, organic matter

\begin{tabular}{|cccccccccc|}
\hline pH & $\begin{array}{c}\text { EC } \\
\left(\mathrm{dS} \mathrm{m}^{-1}\right)\end{array}$ & $\begin{array}{c}\text { Moisture } \\
(\%)\end{array}$ & Ash (\%) & OC (\%) & OM (\%) & N (\%) & P (\%) & K (\%) & C/N ratio \\
\hline 7.7 & 6.75 & 18 & 55 & 26.1 & 45 & 0.84 & 0.23 & 0.7 & 31.07 \\
\hline
\end{tabular}

control was performed at different growth stages of sugar beet. Diazinon insecticide was used twice with seven days interval to control the beet armyworm (Spodoptera exigua). All of the experimental plots were well watered until 8 leaves stage to ensure plant establishment and then the irrigation treatments were implemented. Irrigation interval was determined based on soil moisture discharge. Soil moisture was measured by gravimetric method. According to the irrigation depth for sugar beet, the irrigation interval was determined such that the water requirement of the plant was fully met with 5-day irrigation intervals and a moderate water stress imposed with irrigation intervals of 10 days. All cow manure was mixed with soil prior to sowing. In addition, one third of the urea fertilizer was applied during planting and two thirds at 4 to 6 leaves stage. Other recommended fertilizers including triple superphosphate $\left(75 \mathrm{~kg} \mathrm{ha}^{-1}\right)$ and potassium sulfate $(100 \mathrm{~kg}$ $\mathrm{ha}^{-1}$ ) were incorporated into the soil prior to sowing.

\section{Measurement of traits}

Sugar beet plants were harvested manually on October 1 and 31, excluding some plants to exclude a border effect. The harvested taproots were separated from the leaves and their fresh weight was measured and converted to tons per hectare and considered as root yield. The leaves were open air dried and their weight was measured. Ten taproots were randomly selected and their mean diameter was recorded. The percentage of root sugar was measured by the colorimetric method described by DuBois et al. (1956) at the Laboratory of Food Science \& technology, Faculty of Agriculture, Sanandaj Branch, Islamic Azad University. Sugar yield per unit area was obtained through multiplying the sugar percent by root yield.

\section{Statistical analysis}

The recorded data were subjected to analysis of variance and the least significant difference (LSD) test was used to compare the means. The statistical analyses were performed using SAS software (SAS Institute Inc., Cary, NC, USA).

\section{Results}

\section{Root yield}

Analysis of variance showed that fertilizer treatment statistically affected root yield while irrigation interval, harvest date and interactive effects were not significant (Table 3). The highest yield per unit area was in the N+FYM treatment (50\% cow manure $+50 \%$ nitrogen) with increase rates of 28 and $32 \%$ compared to the $\mathrm{N}$ (100\% nitrogen) and FYM (100\% cow manure) treatments, respectively (Table 4).

\section{Sugar content and yield}

Sugar content was affected by harvest date and the interactions of three factors, but irrigation interval and fertilizer did not have independent significant effect on the sugar content of roots (Table 3). The triple interactive effects of factors on sugar content was shown. This was due to the significant interaction effect of two harvest dates on root sugar content at the water deficit conditions, and the application of $100 \%$ nitrogen fertilizer (WD and $\mathrm{N}$ treatment composition). A one-month delay in harvesting increased the sugar content by about two times more than that of the early harvesting date. In other cases, there was no significant difference between the two harvesting dates in root sugar content (Fig. 2A). A similar result was observed in terms of the response of sugar yield to the interaction of the three factors. When sugar beet was under water deficit

Table 3. Analysis of variance of sugar beet traits. ns, ${ }^{\star}$ and ${ }^{\star *}$ : Non-significant and significant at 5 and $1 \%$ levels of probability, respectively

\begin{tabular}{|c|c|c|c|c|c|c|}
\hline Source of variation & df & Root yield & Sugar content & Sugar yield & Root diameter & Leaf dry weight \\
\hline Replication & 2 & ns & ns & ns & ns & ns \\
\hline Irrigation (I) & 1 & ns & ns & ns & $*$ & ns \\
\hline $\mathrm{E}_{\mathrm{a}}$ & 2 & - & - & - & - & - \\
\hline Fertilizer (F) & 2 & * & ns & ns & ** & * \\
\hline $\mathrm{I} \times \mathrm{F}$ & 2 & ns & ns & ns & ns & * \\
\hline $\mathrm{E}_{\mathrm{b}}$ & 8 & - & - & - & - & - \\
\hline Harvest date $(\mathrm{H})$ & 1 & ns & * & ns & ns & ns \\
\hline $\mathrm{I} \times \mathrm{H}$ & 2 & ns & ns & ns & ns & ns \\
\hline $\mathrm{F} \times \mathrm{H}$ & 2 & ns & ns & ns & ns & ns \\
\hline $\mathrm{I} \times \mathrm{F} \times \mathrm{H}$ & 2 & ns & * & * & ns & ns \\
\hline $\mathrm{E}_{\mathrm{c}}$ & 12 & - & - & - & - & - \\
\hline
\end{tabular}


Table 4. Interactive effects of irrigation, fertilizer and harvest date on root yield $\left(\mathrm{t} \mathrm{ha} \mathrm{h}^{-1}\right)$. N, 100\% recommended dose of nitrogen fertilizer; FYM, 100\% recommended dose of farmyard manure; N+FYM, combination use of 50\% nitrogen and $50 \%$ farmyard manure. Means of treatments with the same letter (for each factor separately) are not significantly different at $P \leq 0.05$ according to the LSD test

\begin{tabular}{|c|c|c|c|c|c|}
\hline \multirow[t]{2}{*}{ Irrigation } & \multirow[t]{2}{*}{ Harvest date } & \multicolumn{3}{|c|}{ Fertilizer } & \multirow[t]{2}{*}{ Means of irrigation treatments } \\
\hline & & $\mathbf{N}$ & FYM & N+FYM & \\
\hline \multirow[t]{3}{*}{ Well watered } & October $1^{\text {st }}$ & 33.40 & 23.96 & 43.66 & \\
\hline & October $31^{\text {st }}$ & 33.82 & 36.42 & 46.20 & \\
\hline & & & & & $36.24 \mathrm{a}$ \\
\hline \multirow[t]{3}{*}{ Water deficit } & October $1^{\text {st }}$ & 36.92 & 40.10 & 49.66 & \\
\hline & October $31^{\text {st }}$ & 36.90 & 36.02 & 41.32 & \\
\hline & & & & & $40.15 \mathrm{a}$ \\
\hline Means of fertilizer treatments & & $35.26 \mathrm{~b}$ & $34.13 \mathrm{~b}$ & $45.21 \mathrm{a}$ & \\
\hline
\end{tabular}

stress and much nitrogen fertilizer was available, early harvesting resulted in a significant drop in sugar yield (Fig. 2B).

\section{Root diameter}

Root diameter was affected by irrigation interval and fertilizer application, but harvesting dates had no significant effect (Table 3). Increased irrigation interval (moderate drought stress conditions) caused a significant increase in sugar beet root diameter (Table 5). The highest root diameter was obtained by application of combined nitrogen fertilizer and cow manure treatment, resulting in increased root diameter by 21 and $24 \%$ compared to individual application of nitrogen fertilizer and cow manure, respectively (Table 5).

\section{Leaf dry weight}

ANOVA analysis showed no significant effect of irrigation interval and harvesting date on leaf dry weight, while the effect of fertilizer and interaction of irrigation and fertilizer were significant (Table 3). Interactive effect of irrigation interval and fertilizer indicated that in the well watered conditions the plant response to nitrogen was better in terms of leaf growth, but under water deficit stress, the application of $100 \%$ nitrogen fertilizer caused loss of leaf dry weight (Fig. 3). Comparison of fertilizer treatments showed that the integrated treatment $(\mathrm{N}+\mathrm{FYM})$ produced the highest dry weight of leaves (Table 6). The application of integrated fertilizer treatment in both irrigation regimes especially under water deficit conditions, was beneficial in increasing leaf dry weight (Fig. 3).

\section{Discussion}

The significant improvement in root yield of sugar beet was obtained by fertilizer treatment of N+FYM (urea fertilizer and cow manure) than when these fertilizers were applied separately. A study by Lehrsch et al. (2015) suggested that the application of cattle manure or compost in sugar beet cultivation could be effective to meet plant nitrogen requirements. Faraji et al. (2015) also reported that the application of chemical fertilizers combined with organic fertilizers such as cow manure improved qualitative and quantitative traits of sugar beet. Similar results were obtained by Amini et al. (2017) who showed thst combined application of manure and urea fertilizer
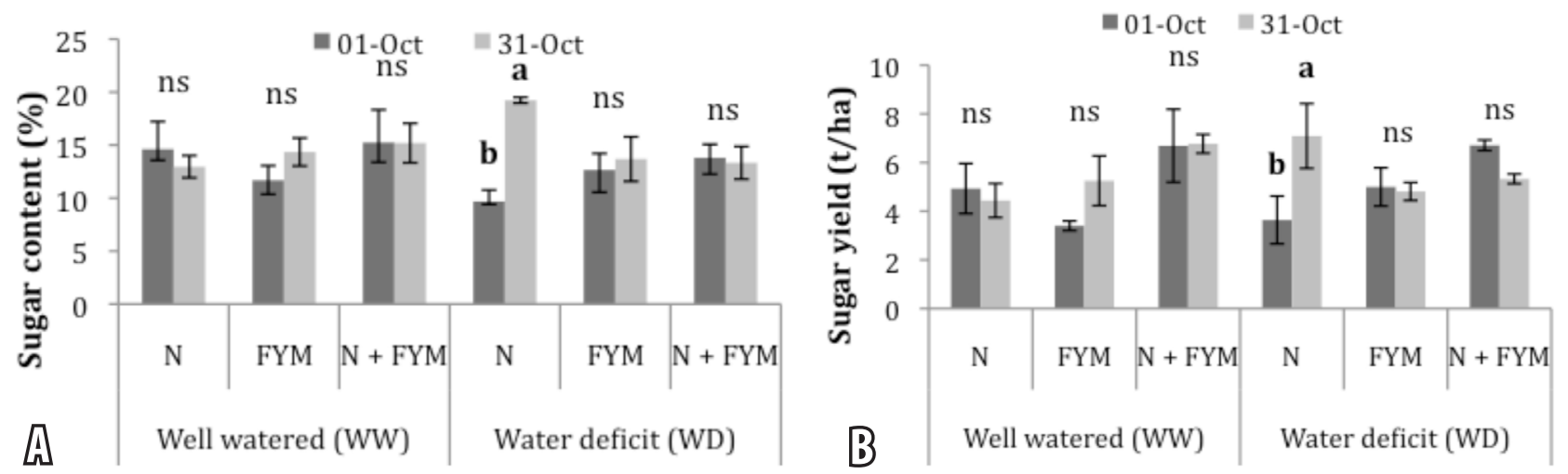

Fig.2. Interactive effects of irrigation, fertilizer and harvest date on sugar content (A) and sugar yield (B). N, 100\% recommended dose of nitrogen fertilizer; FYM, $100 \%$ recommended dose of farmyard manure; N+FYM, combination use of 50\% nitrogen and $50 \%$ farmyard manure. The means of two harvest dates are compared by the LSD test and slicing method. Vertical bars indicate the standard error of the means. 
Table 5. Interactive effects of irrigation, fertilizer and harvest date on root diameter $(\mathrm{cm})$. N, 100\% recommended dose of nitrogen fertilizer; FYM, 100\% recommended dose of farmyard manure; N+FYM, combination use of 50\% nitrogen and 50\% farmyard manure. Means of treatments with the same letter (for each factor separately) are not significantly different at $P \leq 0.05$ according to the LSD test

\begin{tabular}{|c|c|c|c|c|c|}
\hline \multirow[t]{2}{*}{ Irrigation } & \multirow[t]{2}{*}{ Harvest date } & \multicolumn{3}{|c|}{ Fertilizer } & \multirow[t]{2}{*}{ Means of irrigation treatments } \\
\hline & & $\mathbf{N}$ & FYM & N+FYM & \\
\hline \multirow[t]{3}{*}{ Well watered } & October $1^{\text {st }}$ & 5.0 & 5.1 & 7.1 & \\
\hline & October $31^{\text {st }}$ & 6.0 & 4.9 & 7.2 & \\
\hline & & & & & $5.9 \mathrm{~b}$ \\
\hline \multirow[t]{3}{*}{ Water deficit } & October $1^{\text {st }}$ & 6.8 & 7.0 & 7.5 & \\
\hline & October $31^{\text {st }}$ & 6.7 & 6.9 & 7.7 & \\
\hline & & & & & $7.1 \mathrm{a}$ \\
\hline Means of fertilizer treatments & & $6.1 \mathrm{~b}$ & $6.0 \mathrm{~b}$ & $7.4 \mathrm{a}$ & \\
\hline
\end{tabular}

reduced the concentration of nitrate in potato tubers while yields were similar to these after $100 \%$ urea application. Bokhtiar et al. (2008) studied the effects of different fertilizer combinations on growth, yield and quality of sugarcane and recommended the combination of organic and inorganic fertilizers in order to maintain soil fertility and achieve high yields. Also, the results of experiments on sugarcane production in calcareous soils showed that the integrated use of organic and inorganic fertilizers improved sugar yield, sugar quality and soil fertility (Umesh et al. 2013). Miri et al. (2009) showed that the effect of manure application on improving potato yield was due to supply of some nutrients required by the plant, improvement of soil physical and chemical properties, elevation of soil water holding capacity and enhancement of micronutrient uptake.

The interactive effects of irrigation, fertilizer and harvest date on sugar content and yield (Fig. 2) demonstrated that when the plant is under moderate water deficit stress while being supplied with high availability of nitrogen, it is essential to delay the planting date in order to avoid the loss of root sugar. The changes in root sugar content depend on the weather conditions during the last growth stage of sugar beet. A fall of air temperature in late October in this area (Fig. 1) can be considered as a key factor that increases sugar accumulation in the presence of sufficient nitrogen and reduced soil moisture. Positive effects of delayed harvesting on root sugar have been reported by some other authors. The results of a 4-year study on two sugar beet cultivars showed that a one-month delay in harvest resulted in an average $17 \%$ increase in sugar yield in both cultivars (Jozefyova et al. 2003). Yousefabadi and Abdollahian-Noghabi (2011) in a study on the effect of nitrogen fertilizer splitting and four harvesting dates with one-month intervals on sugar beet, found that with a delay in harvesting, the root sugar content increased from $12.8 \%$ in the first harvest to $15.2 \%$ in the last harvest. In addition, sugar yield increased from 5.1 tons per hectare in the first harvest to 10.4 tons per hectare in the last harvest.

The growth of sugar beet root was promoted by moderate drought stress (Table 4). It seems that sugar beet allocates more photo-assimilates to root growth under deficit irrigation conditions, which can lead to greater root development and as a result, an increase in the root diameter. Under soil water deficit, root growth is less affected than shoot growth, and the root to shoot ratio is typically increased in response to drought stress (Marschner 1995). Drought stress can reduce leaf growth and relatively increase the allocation of dry matter to the roots and thus increase the root/shoot ratio (Shaw et al. 2002; Rauf, Sadaqat 2007). Under water deficit stress, plants respond to growth constraints by exporting more carbon resources to the roots to maintain root efficacy (Durand et al. 2016).

Table 6. Interactive effects of irrigation, fertilizer and harvest date on leaf dry weight ( $\left.\mathrm{g} \mathrm{plant}^{-1}\right)$. N, 100\% recommended dose of nitrogen fertilizer; FYM, 100\% recommended dose of farmyard manure; N+FYM, combination use of 50\% nitrogen and 50\% farmyard manure. Means of treatments with the same letter (for each factor separately) are not significantly different at $P \leq 0.05$ according to the LSD test

\begin{tabular}{|c|c|c|c|c|c|}
\hline \multirow[t]{2}{*}{ Irrigation } & \multirow[t]{2}{*}{ Harvest date } & \multicolumn{3}{|c|}{ Fertilizer } & \multirow[t]{2}{*}{ Means of irrigation treatments } \\
\hline & & $\mathbf{N}$ & FYM & N+FYM & \\
\hline \multirow[t]{3}{*}{ Well watered } & October $1^{\text {st }}$ & 21.30 & 12.47 & 18.63 & \\
\hline & October $31^{\text {st }}$ & 20.10 & 13.63 & 21.47 & \\
\hline & & & & & $17.94 \mathrm{a}$ \\
\hline \multirow[t]{3}{*}{ Water deficit } & October $1^{\text {st }}$ & 12.53 & 14.03 & 19.70 & \\
\hline & October $31^{\text {st }}$ & 15.53 & 16.70 & 17.70 & \\
\hline & & & & & $16.03 \mathrm{a}$ \\
\hline Means of fertilizer treatments & & $17.37 \mathrm{a}$ & $14.21 \mathrm{~b}$ & $19.38 \mathrm{a}$ & \\
\hline
\end{tabular}




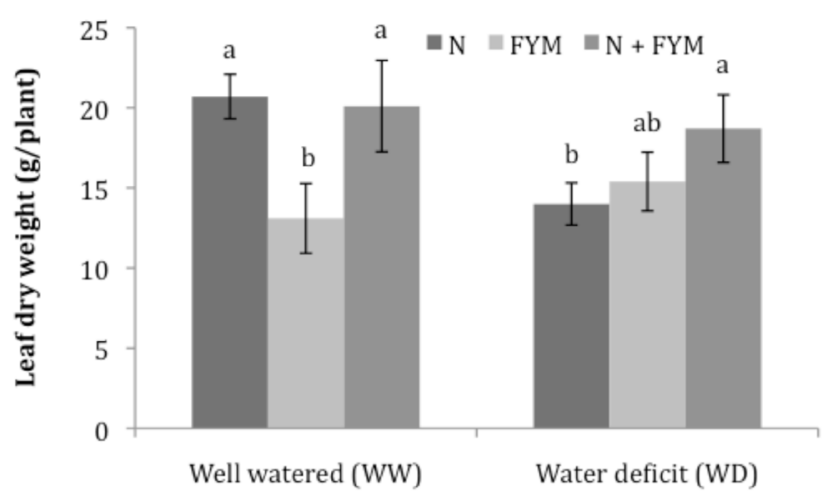

Fig.3. Interactive effects of irrigation and fertilizer on leaf dry weight. N, $100 \%$ recommended dose of nitrogen fertilizer; FYM, $100 \%$ recommended dose of farmyard manure; N+FYM, combination use of $50 \%$ nitrogen and 50\% farmyard manure. The means of two harvest dates are compared by the LSD test and slicing method. Vertical bars indicate the standard error of the means.

The increase in root diameter due to the application of $\mathrm{N}+\mathrm{FYM}$ treatment can be explained by the role of manure in improving soil texture and allowing further root growth, the effect of nitrogen fertilizer on improving vegetative and root growth. The addition of organic fertilizers, including cow manure to soil increases the aggregate stability, the water infiltration rate, water holding capacity and decreases soil bulk density (Barzegar et al. 2002). The application of organic fertilizer that included compost and cow manure in a three-year experiment in potato cultivation reduced soil bulk density. In addition, organic fertilizers generally increased the potato yield by 23,27 and $11 \%$ compared to the control, during three consecutive years, respectively (Porter et al. 1999). Bandyopadhyay et al. (2010) found that the integrated application of farmyard manure and conventional chemical fertilizers, on the one hand significantly reduced the soil bulk density and resistance and, on the other hand increased the hydraulic conductivity and organic matter content of soil, as well as increased soybean yield through increasing water and nutrient use efficiency.

Response of sugar beet leaf growth to the interaction of irrigation interval and fertilizer (Fig. 3) indicated that the presence of farmyard manure in the fertilizer composition can improve leaf growth under drought stress conditions, which may be due to increased soil water holding capacity imparted by the application of cow manure. Studies have shown that animal manure increases water storage in soil and improves uptake of nutrients by plants, thereby improving photosynthesis and shoot growth (Barzegar et al. 2002; Miri et al. 2009). The results of experiments conducted by Bandyopadhyay et al. (2010) also indicated that combined farmyard manure and chemical fertilizer treatment increased leaf area index and shoot growth in soybean plants. They attributed the increase of leaf area index in combined treatment to the production of new leaves and increase in the size of leaves.

\section{Conclusions}

The prominent feature of the present study was that the growth and yield responses of sugar beet to the combined effects of harvest time, fertilization and irrigation factors were examined. The results showed that the integrated use of 50\% FYM and 50\% nitrogen fertilizer increased root growth and yield, such that the need of application of $100 \%$ of the recommended nitrogen fertilizer was eliminated. Therefore the removal of half of the recommended nitrogen dose and substitution of it with FYM can reduce the costs and the risks of soil, water and plant contamination with nitrogen fertilizer residues as well as increase crop yields. The significant interactive effect of irrigation, fertilizer and harvest date on sugar content and yield in this study showed a need to consider the harvest date. Under conditions of $100 \%$ nitrogen fertilizer application and moderate drought stress, late harvest of sugar beet can be recommended to prevent the loss of root sugar content and yield.

\section{References}

Amini R., Dabbagh Mohammadi-Nasab A., Mahdavi S. 2017. Effect of organic fertilizers in combination with chemical fertilizer on tuber yield and some qualitative characteristics of potato (Solanum tuberosum L.). J. Agroecol. 9: 734-748. / In Persian/

Bandyopadhyay K.K., Misra A.K., Ghosh P.K., Hati K.M. 2010. Effect of integrated use of farmyard manure and chemical fertilizers on soil physical properties and productivity of soybean. Soil Tillage Res. 110: 115-125.

Barzegar A.R., Yousefi A., Daryashenas A. 2002. The effect of addition of different amounts and types of organic materials on soil physical properties and yield of wheat. Plant Soil 247: 295-301.

Bayu W., Rethman N.F.G., Hammes P.S., Alemu G. 2006. Effects of farmyard manure and inorganic fertilizers on sorghum growth, yield, and nitrogen use in a semi-arid area of Ethiopia. J. Plant Nutr. 29: 391-407.

Bokhtiar S.M., Paul G.C., Alam K.M. 2008. Effects of organic and inorganic fertilizer on growth, yield, and juice quality and residual effects on ratoon crops of sugarcane. J. Plant Nutr. 31: 1832-1843.

Camposeo S., Rubino P. 2003. Effect of irrigation frequency on root water uptake in sugar beet. Plant Soil 253: 301-309.

Choluj D., Karwowska R., Jasińska M., Haber G. 2004. Growth and dry matter partitioning in sugar beet plants (Beta vulgaris L.) under moderate drought. Plant Soil Environ. 50: 265-272.

Davidoff B., Hanks R.J. 1989. Sugar beet production as influenced by limited irrigation. Irrig. Sci. 10: 1-17.

DuBois M., Gilles K.A., Hamilton, J.K., Rebers P.A., Smith F. 1956. Colorimetric method for determination of sugars and related substances. Anal. Chem. 28: 350-356.

Durand M., Porcheron B., Hennion N., Maurousset L., Lemoine R., Pourtau N. 2016. Water deficit enhances C export to the roots in Arabidopsis thaliana plants with contribution of 
sucrose transporters in both shoot and roots. Plant Physiol. 170: 1460-1479.

Faraji S., Rafieiolhossaini M., Abbasi Soorki A. 2015. The effect of solitary and combined application of organic and biological manure and chemical fertilizer on some of the qualitative and quantitative properties of sugar beet. Agric. Crop Manage. 17: 789-800. /in Persian/

Fekadu E., Kibret K., Melese A., Bedadi B. 2018. Yield of faba bean (Vicia faba L.) as affected by lime, mineral P, farmyard manure, compost and rhizobium in acid soil of Lay Gayint District, northwestern highlands of Ethiopia. Agric. Food Secur. 7: 16.

Groves S.J., Bailey R.J. 1997. The influence of sub-optimal irrigation and drought on crop yield, $\mathrm{N}$ uptake and risk of $\mathrm{N}$ leaching from sugar beet. Soil Use Manage. 13: 190-195.

Hang AnN., Miller D.E. 1986. Responses of sugar beet to deficit, high-frequency sprinkler irrigation. I. Sucrose accumulation, and top and root dry matter production. Agron. J. 78: 10-14.

Ibrahim M., Hassan A., Iqbal M., Valeem E.E. 2008. Response of wheat growth and yield to various levels of compost and organic manure. Pakistan J. Bot. 40: 2135-2141.

Jozefyová L., Pulkrábek J., Urban J. 2003. The influence of harvest date and crop treatment on the production of two different sugar beet variety types. Plant Soil Environ. 49: 492-498.

Kiymaz S., Ertek A. 2015. Yield and quality of sugar beet (Beta vulgaris L.) at different water and nitrogen levels under the climatic conditions of Kirsehir, Turkey. Agric. Water Manage. 158: 156-165.

Lehrsch G.A., Brown B., Lentz R.D., Johnson-Maynard J.L., Leytem A.B. 2015. Sugar beet yield and quality when substituting compost or manure for conventional nitrogen fertilizer. Agron. J. 107: 221-231.

Mahmoodi R., Maralian H., Aghabarati A. 2008. Effects of limited irrigation on root yield and quality of sugar beet (Beta vulgaris L.). Afr. J. Biotechnol. 7: 4475-4478.

Malik A., Shakir A.S., Latif M., Ajmal M. 2018. Performance evaluation of the raised-bed planting and potential in improving sugar beet yield and water use efficiency in Pakistan. Sugar Tech 20: 540-551.

Marschner H. 1995. Mineral Nutrition of Higher Plants. Academic Press, London, 889 p.

Miri Z., Asghari J., Penahi Kord-Laghari Kh. 2009. Effect of irrigation regimes and fertilizer combinations on yield of two potato (Solanum tuberosum L.) cultivars in Freidan. J. Crop Prod. Process. 12: 177-186. /In Persian/

Monti A., Brugnoli E., Scartazza A., Amaducci M.T. 2006. The effect of transient and continuous drought on yield, photosynthesis and carbon isotope discrimination in sugar beet (Beta vulgaris L.). J. Exp. Bot. 57: 1253-1262.
Moore A., Stark J., Brown B., Hopkins B. 2009. Southern Idaho fertilizer guide, sugar beets. http://www.extension.uidaho. edu/publishing/pdf/CIS/CIS1174.pdf

Morillo-Velarde R. 2010. Water management in sugar beet. Sugar Tech 12: 299-304.

Oliveira M.D., Carranca C.F., Oliveira M.M., Gusmao M.R. 1993. Diagnosing nutritional status of sugarbeet by soil and petiole analysis. In: Fragoso M.A.C., van Beusichem M.L. (eds) Optimization of Plant Nutrition. Kluwer Academic Publishers, The Netherlands, pp. 147-151.

Porter G.A., Bradbury W.B., Sisson J.A., Opena G.B., Mcburine J.C. 1999. Soil management and supplement irrigation effect on potato: I. Soil properties, tuber yield and quality. Agron. J. 91: $416-425$.

Rauf S., Sadaqat H.A. 2007. Effects of varied water regimes on root length, dry matter partitioning and endogenous plant growth regulators in sunflower (Helianthus annuus L.). J. Plant Interact. 2: 41-51.

Reddy S., Neufeld J., Gallian J., Neibling H., Ellsworth J., Gortsema S. 2007. Sugarbeet irrigation management using watermark moisture sensors. http://www.extension.uidaho.edu/ publishing/pdf/CIS/CIS1140.pdf

Saidia P.S., Mrema J.P. 2017. Effects of farmyard manure and activated effective microorganisms on rain-fed upland rice in Mwanza, Tanzania. Org. Agr. 7: 83-93.

Shaw B., Thomas T.H., Cooke D.T. 2002. Responses of sugar beet (Beta vulgaris L.) to drought and nutrient deficiency stress. Plant Growth Regul. 37: 77-83.

Taleghani D.F., Moharamzadeh M., Hemayati S.S., Mohammadian R., Farahmand R. 2011. Effect of sowing and harvest time on yield of autumn-sown sugar beet in Moghan region in Iran. Seed Plant Prod. J. 27: 355-371. /In Persian/

Tsialtas J.T, Maslaris N. 2005. Effect of N fertilization rate on sugar yield and non-sugar impurities of sugar beets (Beta vulgaris) grown under Mediterranean conditions. J. Agron. Crop Sci. 191: 330-339.

Umesh U.N., Kumar V., Alam M., Sinha S.K., Verma K. 2013. Integrated effect of organic and inorganic fertilizers on yield, quality parameter and nutrient availability of sugarcane in calcareous soil. Sugar Tech 15: 365-369.

Yousefabadi V., Abdollahian-Noghabi M. 2011. Effect of split application of nitrogen fertilizer and harvest time on the root yield and quality characteristics of sugar beet. Iran. J. Crop Sci. 13: 521-532. /In Persian/

Zare Abyaneh H., Jovzi M., Albaji M. 2017. Effect of regulated deficit irrigation, partial root drying and $\mathrm{N}$-fertilizer levels on sugar beet crop (Beta vulgaris L.). Agric. Water Manage. 194: 13-23. 